\title{
The determination of the rolling resistance coefficient of a passenger vehicle with the use of roller test bench method
}

\author{
Bartłomiej Pałasz ${ }^{1}$, Konrad J. Waluśs ${ }^{*}$, and Eukasz Warguła ${ }^{2}$ \\ ${ }^{1}$ Alumnus Poznan University of Technology \\ ${ }^{2}$ Poznań University of Technology, Piotrowo 3, 60-965 Poznań, Poland
}

\begin{abstract}
Contemporary vehicle are designer to be eco-friendly. One of the factors limiting the energy consumption of driving processes is a low value of the rolling resistance coefficient. The rolling resistance depends on the construction features of a tire, exploitation conditions and the type of surface the car moves on. This article presents the results of experimental research of determining the rolling resistance coefficient with the use of laboratory method of roller test bench. The results presented here are a part of a wider research of determining the rolling resistance coefficient and the influence of research method on its value.
\end{abstract}

Keywords: rolling resistance coefficient, car transport, research methodology, roll test, car tires

\section{Introduction}

Nowadays cars are used as means of transport to carry people, animals and goods. In 2003 the estimated number of cars around the world was about 700 million. In 2020 this number is predicted to reach 1.2 billion. Worldwide car production in 2003 was 42 million cars a year whereas trucks 18.6 million. [1]. Vehicle designers aim the cars to be more and more ecological [2-4]. In order to lower energy consumption in vehicles the following solutions are used [1]:

- downsizing - lowering combustion engines capacity [5].

- increasing the efficiency of combustion engines,

- unconventional drives,

- lower the weight of the vehicle,

- reducing the aerodynamic resistance of the vehicle,

- reducing the rolling resistance $[6,7]$.

Wheel rolling resistance depends on tire construction features such as: tire width and height, tire offset diameter, kind of tread, speed index, number of cords plies, kind of fabrics in carcass and belt plies, rubber mixture of the tread and its hardness, rim width and the material it's made of [1]. Another factor influencing the rolling resistance is the kind of

\footnotetext{
* Corresponding author: konrad.walus@put.poznan.pl

Reviewers: Wiestawa Piekarska, Ján Vavro Jr.
} 
surface, its state as well as micro and makrotexture [8-16]. The rolling resistance is also influenced by movement conditions, speed, wheel load, tire pressure, air temperature, rolling direction and tire tread wear [1, 8-15, 17-21].

The main reason for the occurrence of the rolling resistance is viscoelasticity properties of rubber objects [22]. Owing to this property, when tires are deformed they cause the energy dissipates as heat. While movement there is a displacement of forces causing the occurrence of momentum that resists the turning of the vehicle wheel. The value of this force is energy loss caused by tire deformation at a contact point with a hard surface This force is called the rolling resistance force [22]. The rolling resistance of a rubbered wheel is defined by a value of the rolling resistance force or the value of the rolling resistance coefficient. This article presents the results of experimental research of determining the rolling resistance coefficient with the use of laboratory method of roller test bench.

\section{Research methods}

There are two research methods of determining the rolling resistance coefficient : the laboratory methods and road tests. The division of methods is presented in Figure 1.

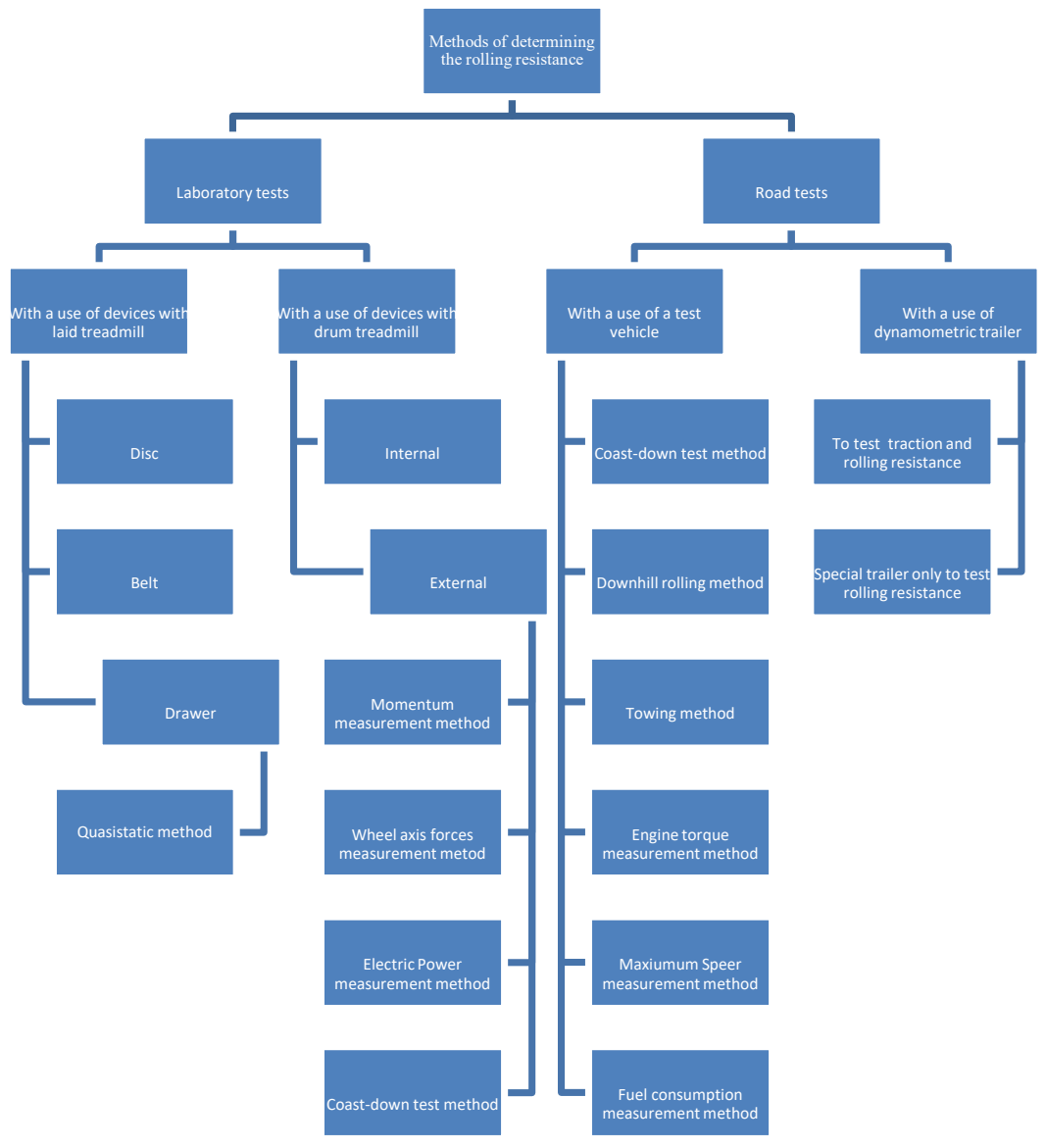

Fig. 1. Laboratory methods and road tests for determining the rolling resistance coefficient [1]

The values of the rolling resistance coefficient for passenger vehicles and trucks depending on the kind of surface they move at are presented in Table 1. 
Table 1. The rolling resistance coefficients sheet [12]

\begin{tabular}{|l|c|c|}
\hline \multicolumn{1}{|c|}{ Kind of the surface and bed } & Passenger vehicles & Trucks \\
\hline Smooth asphalt-concrete & 0.012 & 0.010 \\
\hline Smooth concrete & 0.014 & 0.012 \\
\hline Rough concrete & 0.015 & 0.013 \\
\hline Granite blocks in a very good state & 0.016 & 0.014 \\
\hline Granite blocks in a poor state & 0.025 & 0.023 \\
\hline Stone blocks in a poor state & 0.033 & 0.030 \\
\hline Road cobbled with field stones & 0.040 & 0.035 \\
\hline Ground road in an avarege state & \multicolumn{2}{|c|}{$0.050-0.140$} \\
\hline Ground road sandy and moisty & \multicolumn{2}{|c|}{$0.150-0.0 .300$} \\
\hline Dry sand & \multicolumn{2}{|c|}{$0.060-0.110$} \\
\hline Grass-covered area & \multicolumn{2}{|c|}{} \\
\hline Snow & \multicolumn{2}{|c|}{} \\
\hline
\end{tabular}

\subsection{Research object}

In order to carry out the test the passenger car BMW series 3 E90 model 320d was used. It's a sedan powered by turbocharged Diesel engine of the capacity of $1995 \mathrm{~cm}^{3}$ and $163 \mathrm{hp}$. The car was produced in 2005 and has rear axis drive. The car was equipped with aluminum rims and tires with the following parameters, Table 2 .

Table 2. Parameters of aluminium rims and tires

\begin{tabular}{|l|c|}
\hline Rim model & BMW Styling 268 \\
\hline Rim diameter & $16 "$ \\
\hline Rim width & 7 \\
\hline Rim offset/ ET & 31 \\
\hline Rim nuts spacing & $5 \times 120 \mathrm{~mm}$ \\
\hline Tire manufacturer & BRIDGESTONE \\
\hline Tire model & Turanza 001 \\
\hline Tire profile & 205 \\
\hline Tire width & 55 \\
\hline Tire diameter & $16 ”$ \\
\hline Tire load index & 91 \\
\hline Tire Speer index & V \\
\hline Date of production & 35th week of 2015 \\
\hline
\end{tabular}

\subsection{Test equipment}

The research was carried out at regional vehicle test station at Poznan University of Technology. The measurement was made with the use of machine produced by MAHA company Maschinenbau Haldenwang integrated with drive rollers. 


\section{The research methodology of rolling resistance in road conditions}

Before the measurements were made tire pressure had been checked. Next the car was placed on a research stand which is roller test bench. Each test was performed separately for front and rear axis. During the test the rolling resistance force for each wheel was determined as well as braking force. The research for stationary method is presented in Figure 2.
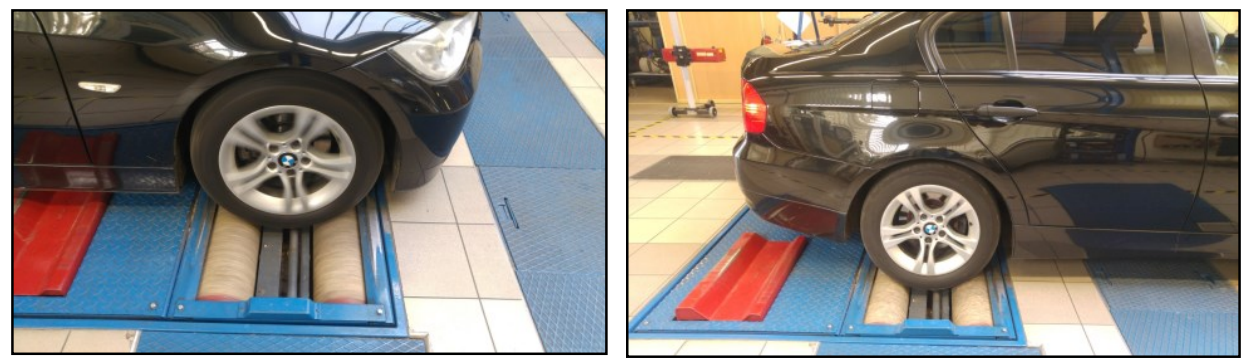

Fig. 2. Research on rolling resistance for front and rear axis of the vehicle

\section{Research results}

The measurement results of rolling resistance force of front and rear axis of a vehicle recorded during the research are presented in figures 3 and 4.

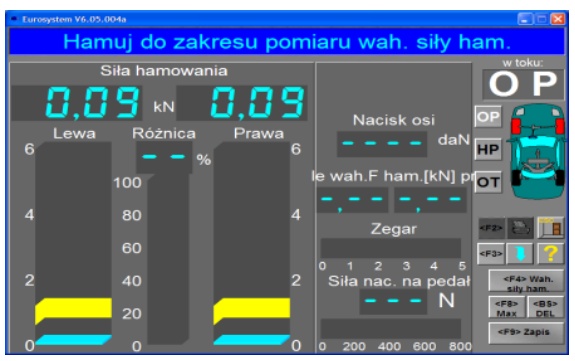

Fig. 3. Screenshot of measurement system for the rolling resistance coefficient of front axis

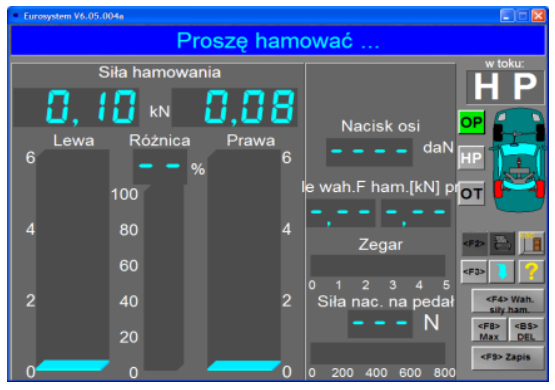

Fig. 4. Screenshot of measurement system for the rolling resistance coefficient of rear axis

During the research on rolling resistance on roller test bench the following values of rolling resistance force for each wheel were obtained. The results are presented in Table 3. 
Table 3. The value of rolling resistance force for wheels of a tested vehicle

\begin{tabular}{|l|c|}
\hline Front left wheel & $0.09 \mathrm{kN}$ \\
\hline Front right Wheel & $0.09 \mathrm{kN}$ \\
\hline Rear left Wheel & $0.10 \mathrm{kN}$ \\
\hline Rear right Wheel & $0.08 \mathrm{kN}$ \\
\hline
\end{tabular}

In order to determine the rolling resistance coefficient using the stationary method it is necessary to know the mass distribution of the tested car. The scales were used and car was weight first entering the scales with front axis and then rear axis. The result for each axis was then divided by 2 in order to obtain the load for each of the vehicle wheels. The results are presented in Table 4.

Table 4. Wheel load of the tested vehicle

\begin{tabular}{|l|c|}
\hline Front left wheel & $427.5 \mathrm{~kg}$ \\
\hline Front right Wheel & $427.5 \mathrm{~kg}$ \\
\hline Rear left Wheel & $399 \mathrm{~kg}$ \\
\hline Rear right Wheel & $399 \mathrm{~kg}$ \\
\hline
\end{tabular}

Using the equation for rolling resistance [17]:

$$
F=m \cdot g \cdot f_{t}
$$

where:

$F$ - rolling resistance force $[\mathrm{N}]$,

$m$ - vehicle mass [kg],

$g$ - standard gravity $\left[\mathrm{m} / \mathrm{s}^{2}\right]$,

$f_{t}$ - rolling resistance coefficient.

After transformation we receive:

$$
f_{t}=\frac{F}{m \cdot g} .
$$

The values of rolling resistance coefficient were determined for each of the wheels, for example:

$$
f_{t}=\frac{90}{427.5 \cdot 9.81}=0.02146
$$

The results of obtained values of rolling resistance coefficient calculated for stationary method on roller test bench. The obtained values of rolling resistance coefficient are presented in Table 5.

Table 5. The values of rolling resistance coefficient determined for stationary method on roller test bench

\begin{tabular}{|l|c|}
\hline Front left wheel & 0.02146 \\
\hline Front right Wheel & 0.02146 \\
\hline Rear left Wheel & 0.02555 \\
\hline Rear right Wheel & 0.02044 \\
\hline \multicolumn{1}{|c|}{ Average value of the coefficient } & $\mathbf{0 . 0 2 2 2 3}$ \\
\hline
\end{tabular}




\section{Summary}

During the research a passenger car was used. The rolling resistance coefficient was determined with the use of stationary method on roller test bench, during which also rolling resistance force was measured which is necessary to turn each of the vehicle wheels. In this method it is necessary to know the exact mass distribution of the tested vehicle which influences significantly the obtained value of the coefficient. For a passenger vehicle moving on an asphalt road the value of rolling resistance coefficient presented in literature sources equals 0.012 .

The values of rolling resistance coefficient determined with the use of experimental research laboratory method vary from the ones in literature sources. The assumed method does not reflect the proper range of interaction of tire with surface. What is more, it can introduce into measurement system interference such as the rolling resistance of the rollers or drive systems. The range of resistance of measurement device is not fully examined which can influence the results. However, also literature sources miss information what method was used to determine the values of rolling resistance coefficient.

It is worth mentioning that lowering the value of rolling resistance coefficient even by a small percent positively influences the economical and ecological aspects of driving. The lower the value of rolling resistance coefficient is the lower fuel consumption is. With such a high number of cars around the world it means saving the natural resources and reducing the amount of exhaust fumes in the environment. It is the reason for a constant research on the reduction of energy consumption of the vehicles, which requires the unification of research methods and determining the ranges of their comparability.

\section{References}

1. S. Tamyra, Opór toczenia opon samochodowych. Wydawnictwo Politechniki Gdańskiej, Gdańsk (2007)

2. M. Idzior, Directions of changes of materials in motorization in view of ecological requirements. MOTOR, 9, 72-87 (2007)

3. W. Piekarski, G. Dzieniszewski, Transport and logistics processes of recycling in terms of ecological safety. Logistyka 5/2015, 461-466 (2015)

4. J. Polasik, K.J. Waluś, The tire pressure monitoring system - an overview of solutions. Logistyka 5/2015, 5363-5367 (2015)

5. P. Zając, L. M. Kołodziejczyk, Silnik spalinowe. WSiP, Warszawa, ISBN 978-83-0207987-0 (2001)

6. S. Taryma, R. Woźniak, Unconventional vehicle wheels. Autobusy. Technika, Eksploatacja, Systemy Transportowe 7-8, 427-432 (2017)

7. M. Domek, Opory ruchu pojazdu oraz minimalizacja oporów toczenia. Napędy i Sterowanie, R. 19, nr 12, 96-100 (2017)

8. M. Dębicki, Car theory. Drive theory (original title in Polish: Teoria samochodu. Teoria napędu) WNT, Warszawa (1969)

9. A. Minchejmer, The theory of a moving car (original title in Polish: Teoria ruchu samochodu). Państwowe Wydawnictwo Naukowe, Warszawa (1960)

10. M. Mitschke, Car Dynamics. T. 1. Drive and braking (original title in Polish: Dynamika Samochodu. T. 1. Napęd i hamowanie). WKŁ, Warszawa (1987)

11. S. Orzełowski, Construction of chassis and car bodies (original title in Polish: Budowa podwozi i nadwozi samochodowych). WSiP, Warszawa, ISBN 83-02-08785-8 (1996) 
12. L. Prochowski, Car vehicles. Movement mechanics (original title in Polish: Pojazdy samochodowe. Mechanika ruchu). WKL, Warszawa ISBN 978-83-206-1701-6 (2008)

13. L. Prochowski, J. Unarski, W. Wach, J. Wicher, Car vehicles. Basics of reconstruction of road accidents (original title in Polish: Pojazdy samochodowe. Podstawy rekonstrukcji wypadków drogowych). WKŁ, Warszawa ISBN 978-83-206-1688-0 (2008)

14. W. Siłka, The theory of a moving car (original title in Polish: Teoria ruchu samochodu). Wydawnictwo Naukowo-Techniczne, Warszawa, ISBN 83-204-2748-7 (2002)

15. J. Wierciński, A. Reza, Road accidents. Vademecum of the court expert (original title in Polish: Wypadki drogowe. Vademecum biegłego sądowego. Wydawnictwo Instytutu Ekspertyz Sądowych, Kraków, ISBN 83-87425-65-6 (2002)

16. H. Taghavifar, A. Mardani, Investigating the effect of velocity, inflation pressure, and vertical load on rolling resistance of a radial ply tire. Journal of Terramechanics Vol. 50, Iss. 2 , 99-106 (2013)

17. A.I. Grishkevich, Automobiles, Theory (original title in Russian: Автомобили, Теория,). Издателъство Вышэишая Школа (1986)

18. J. Reimpell, P. Sponagel, Chassis technology: tires and wheels (original title in German: Fahrwerktechnik: Reifen und Räder). Vogel Buchverlag, Würzburg (1988)

19. W. Siłka, Theory of car motion, part II. Energy consumption of traffic and fuel consumption (original title in Polish: Teoria ruchu samochodu, cz. II. Energochłonność ruchu i zużycia paliwa). WSI, Opole (1994)

20. S. Taryma, R. Woźniak, Passenger car tyres/road rolling resistance measurements on different surfaces. Archiwum Motoryzacji 2, 1-10 (2006)

21. K. Kulikowski, D. Szpica, Determination of directional stiffnesses of vehicles' tires under a static load operation. Eksploatacja i Niezawodność - Maintenance and Reliability 16 (1), 66-72 (2014)

22. MICHELIN, Opór toczenia, a oszczędność paliwa. Societe de Technologie Michelin, (2002) 